\title{
Study of serum electrolytes and minerals in hypothyroidism
}

\author{
Padhiary $\mathbf{M}^{1}$, Mishra $\mathrm{T}^{2}$, Mohanty R.R. ${ }^{3}$, Mishra $\mathrm{S}^{4}$, Mishra S.K. ${ }^{5}$ \\ ${ }^{1}$ Dr Madhusmita Padhiary, M. D Physiology, ${ }^{2}$ Dr Tapaswini Mishra, Assistant Professor, Department of Physiology, IMS \\ \& SUM Hospital Bhubaneswar, Odisha, India. ${ }^{3}$ Dr Rashmi Ranjan Mohanty, Paediatrician, UGPHC, Pattamundai, \\ Odisha, ${ }^{4}$ Dr Srimannarayan Mishra, P.G student, Department of FMT, IMS \& SUM Hospital, Bhubaneswar, ${ }^{5}$ Dr Sandeep \\ Kumar Mishra, P.G student, Department of Paediatrics, IMS \& SUM Hospital, Bhubaneswar Odisha.
}

Address for Correspondence: Dr Madhusmita Padhiary, Department of Physiology, IMS \& SUM Hospital, Bhubaneswar, Odisha. Email: neetho@yahoo.com

\begin{abstract}
Background of the study: Hypothyroidism is known to affect electrolyte, fat, protein and carbohydrate metabolism. Though the effects of thyroid hormones on lipid profile has been well established, the effects on electrolytes and certain minerals like calcium, magnesium and phosphorus is not clear and the underlying mechanisms responsible for these changes are not well understood. Aim and objectives: The objective was to find out the effects of hypothyroidism on certain electrolytes and minerals levels. Materials and methods: The study was carried out in Department of Physiology in collaboration with Medicine, Endocrinology and Biochemistry.100 cases of overt hypothyroidism of both genders aged 25-60 years were chosen,100 age and sex matched healthy controls were chosen. Blood samples were collected from them and serum TSH, total T3, T4, sodium, potassium, calcium, magnesium and phosphorus levels were measured. The values of the above parameters of cases and controls were compared and statistical analysis was made. Results: It was found that the levels of serum sodium, potassium and calcium were significantly decreased in cases than the controls. Serum magnesium and phosphorus were significantly elevated in cases than controls. Conclusion: From this study we were able to conclude that higher the TSH levels, higher will be serum magnesium and phosphorus in the blood and lower will be serum sodium, potassium and calcium levels.
\end{abstract}

Key words: Electrolytes, Hypothyroidism, Minerals, T3, T4, TSH

\section{Introduction}

Hypothyroidism is a clinical entity resulting from the deficiency of thyroid hormones or from their impaired activity. It is a common metabolic disorder in the general population [1]. In India 42 million people are suffering from thyroid diseases, hypothyroidism being the commonest thyroid disorder [2]. Hypothyroidism is 10 times more common in women than men and its prevalence increases with age [3]. Higher prevalence of thyroid disease in women suggests that estrogen might be involved in pathology of thyroid dysfunction. Estradiol has an antagonistic effect on hormones T3 and $\mathrm{T} 4$. The reason being estradiol competes with $\mathrm{T} 3$ and $\mathrm{T} 4$ for binding sites on the receptor proteins $[4,5]$. Hypothyroidism is accompanied by remarkable alterations in the metabolism of water and electrolytes

Manuscript received $4^{\text {th }}$ June 2016

Reviewed: $13^{\text {th }}$ June 2016

Author Corrected: $24^{\text {th }}$ June 2016

Accepted for Publication $6^{\text {th }}$ July 2016
[6,7]. Sodium and potassium are important components of the enzyme sodium potassium ATPase which is a cell membrane enzyme that helps in transport of water and nutrients across the cell membrane. Thyroid hormones regulate the activity of sodium potassium pumps in most of the tissue [8]. Prospective studies show that hypothyroidism is associated with Hyponatremia $[9,10,11$,$] . An impaired urinary dilution capacity due to$ non-osmotic release of antidiuretic hormone as well as increased urinary sodium loss is the major mechanism for hypothyroid induced hyponatremia in rats [12]. Thyroid hormones modulate the expression of sodium potassium ATPase mRNA and protein and hence regulate the activity of this critical component of renal sodium transport [13]. Hypothyroidism could be a cause of hypokalemia. According to Saruta $\mathrm{T}$ et al plasma Renin Activity (PRA) and plasma Aldosterone (PA) may be suppressed in hypothyroidism probably due to 
dysfunction of juxtaglomerular cells and glomerulosa cells in zona glomerulosa respectively and the possibility that suppression of PRA and PA in patients with hypothyroidism is related to exaggerated sodium excretion and decrease in potassium excretion cannot be ruled out (Saruta T et al 1980) [14]. In hypothyroidism, because of low potassium level and increased intracellular sodium concentration results in accumulation of water inside the cells and causing edema. Mineral metabolism like calcium, magnesium and phosphorus is frequently disturbed in thyroid dysfunctions.

Thyroid hormones exert its effects on osteoblasts via nuclear receptors to stimulate bone resorption. [15]. In hypothyroidism there is a depressed turn over due to impaired mobilization of calcium into bone and leads to decrease in blood calcium level. In hypothyroidism increased production of calcitonin can promote tubular reabsorption of phosphate and tubular excretion of calcium [16]. Serum magnesium and phosphorus levels are increased in hypothyroidism $[17,18]$.

\section{Materials and Methods}

The present work was carried out in the Department of Physiology in collaboration with the Department of Medicine, Endocrinology and Biochemistry in IMS and SUM Hospital, Bhubaneswar, on patients attending outpatient department and admitted in the Medicine and Endocrinology Department of the same college and
Hospital, in the period of January 2014 to July 2015. The study type was case-control. The study included 100 clinically established hypothyroid cases and 100 healthy individuals as control groups of both sexes. All the patients having overt hypothyroidism of either sex between the ages 25-60 years were included in the study. Pediatric age group patients with renal disorders, hepatic disorders, bone disorders and diabetes mellitus and patients on medication e.g. diuretics, calcium and iron tablets were excluded in the study. Method of analysis was by taking $2 \mathrm{ml}$ of venous blood sample was drawn from cases and controls and serum was separated. Following Biochemical investigations were carried out in both cases and controls. A. Thyroid hormone Assay: total serum T3, total serum T4, Serum TSH which were measured by E.C.L.I.A (Electro Chemi Luminescence Immuno Assay) method on cobase 411 and serum required for these was 500 $\mu 1 . B$. Serum levels of the following electrolytes and minerals were measured. Serum electrolytes like sodium and potassium were done on ILyte and serum minerals like calcium, magnesium and phosphorus were done on Auto analyser $400+$ and serum required for these tests was $400 \mu$ l. Total serum sodium level by ISE (Ion sensitive electrode) method, total serum Potassium by ISE (Ion sensitive electrode) method, total serum Calcium by O-Cresolphthaleincomplexone method, total serum Magnesium by Chlorophosphonazo III method, total serum Phosphorus by Phosphomolybdate UV method.

\section{Results}

A total of 100 cases and 100 controls were studied. Among the cases $30(30 \%)$ were male and 70 (70\%) were female. In the control group $37(37 \%)$ were male and $53(53 \%)$ were female. There were more females than males among cases. There was also more number of females than males in control group.

Table No.-1: Age distribution of cases and control.

\begin{tabular}{|c|c|c|c|c|}
\hline Age in years & \multicolumn{2}{|c|}{ Cases } & No. & $\%$ \\
\hline & No. & $\%$ & 15 & 15 \\
\hline $31-40$ & 29 & 29 & 42 & 42 \\
\hline $41-50$ & 51 & 51 & 31 & 31 \\
\hline$>50$ & 15 & 15 & 12 & 12 \\
\hline Total Mean \pm SD & 5 & 5 & $40.04 \pm 8.1986$ \\
\hline
\end{tabular}

Table No. 1 shows the highest number (51\%) of cases belonged to the age group 31-40 years. The mean age of case was $35.6900 \pm 8.0487$ with S.E of mean was 0.80487 .

Also there were significant more number of euthyroids in 31-40 years of age in control groups. The mean age of control was $40.04 \pm 8.1986$ with S.E of mean was 0.8198 . 
Table No.-2: Comparison of serum TSH, T3 and T4 in two groups studied.

\begin{tabular}{|c|c|c|c|c|}
\hline Lab variables & $\begin{array}{c}\text { Hypothyroid cases } \\
(\mathrm{n}=100) \\
\text { Mean } \pm \text { SEM }\end{array}$ & $\begin{array}{c}\text { Healthy controls } \\
(\mathrm{n}=100) \\
\text { Mean } \pm \text { SEM }\end{array}$ & t value & value \\
\hline $\mathrm{TSH}(\mu \mathrm{IU} / \mathrm{ml})$ & $59.4475 \pm 4.14390$ & $1.6567 \pm 0.07418$ & 13.94 & $<0.001^{*}$ \\
\hline $\mathrm{T} 3(\mathrm{ng} / \mathrm{dl})$ & $48.4532 \pm 2.76735$ & $101.2810 \pm 1.57358$ & 16.594 & $<0.001^{*}$ \\
\hline $\mathrm{T} 4(\mu \mathrm{g} / \mathrm{dl})$ & $2.9349 \pm 0.13874$ & $8.5377 \pm 0.13528$ & 28.913 & $<0.001^{*}$ \\
\hline
\end{tabular}

Table No. 2 shows when serum levels of TSH,T3 and T4 of cases and controls were compared a significant variation was seen. Serum TSH levels in Hypothyroid cases were found to be significantly increased when compared to healthy controls $(\mathrm{p}<0.001)$. Serum levels of T3 andT4 in hypothyroid cases were found to be significantly decreased when compared to healthy controls $(\mathrm{p}<0.001)$.

Table No.-3: Comparison of serum Sodium(Na), Potassium(K) and Calcium(Ca) levels in cases and controls.

\begin{tabular}{|c|c|c|c|c|}
\hline Lab variables & $\begin{array}{c}\text { Hypothyroid cases } \\
(\mathbf{n = 1 0 0}) \\
\text { Mean } \pm \text { SEM }\end{array}$ & $\begin{array}{c}\text { Healthy controls(n=100) } \\
\text { Mean } \pm \text { SEM }\end{array}$ & t value & p value \\
\hline Sodium(meq/L) & $129.448 \pm 0.3083$ & $141.0600 \pm 0.19113$ & 36.462 & $<0.001 *$ \\
\hline Potassium(meq/L) & $3.0942 \pm 0.0401$ & $3.9683 \pm 0.0340$ & 24.070 & $<0.001 *$ \\
\hline Calcium(mg/dl) & $7.9243 \pm 0.0285$ & $9.3151 \pm 0.0420$ & 27.384 & $<0.001 *$ \\
\hline
\end{tabular}

Table No. 3 shows when serum levels of sodium, potassium and calcium of cases and controls were compared a significant variation was seen. The levels of calcium and sodium were significantly decreased in cases when compared to controls $(p<0.001)$. Serum potassium levels were found to be less than that of controls and difference was statistically significant $(\mathrm{p}<0.001)$.

Table No-4: Comparison of serum Magnesium and Phosphorus levels in cases and controls.

\begin{tabular}{|c|c|c|c|c|}
\hline Lab variables & $\begin{array}{c}\text { Hypothyroid } \\
\text { cases(n=100) } \\
\text { Mean } \pm \text { SEM }\end{array}$ & $\begin{array}{c}\text { Healthy } \\
\text { controls(n=100) } \\
\text { Mean } \pm \text { SEM }\end{array}$ & t value & p value \\
\hline Phosphorus(mg/dl) & $4.9382 \pm 0.0147$ & $3.3344 \pm 0.2001$ & 7.99 & $<0.001^{*}$ \\
\hline Magnesium(mg/dl) & $2.9131 \pm 0.0278$ & $2.1418 \pm 0.0274$ & 19.72 & $<0.001^{*}$ \\
\hline
\end{tabular}

Table No. 4 shows when serum levels of phosphorus and magnesium of cases and controls were compared a significant variation was seen. Among the minerals, phosphorus and magnesium levels in serum were elevated in patients with hypothyroidism when compared to controls and the difference was statistically significant $(\mathrm{p}<0.001)$.

\section{Discussion}

Hypothyroidism is a condition in which the body suffers from insufficient thyroid hormones. Since thyroid hormones act as a central regulator of various body functions and control various metabolisms, more importantly lipid metabolism and that of various electrolytes, the hypothyroid patients generally suffer from a slow metabolism resulting in dyslipidemias and electrolyte disturbances. Hypothyroidism is a very common condition and seen more in females than males. The present study showed majority of the patients were women $(70 \%)$ and in the age group of 31 to 40 years which is in accordance with study done by RoopaMurgod et al (Roopa M et al 2012) [19]. The higher prevalence of thyroid disease in women suggests that estrogen might be involved in the pathophysiology of thyroid dysfunction. Estradiol has an antagonistic effect on the hormones T3 and T4. The reason being, estradiol competes with $\mathrm{T} 3$ and $\mathrm{T} 4$ for binding sites on the receptor proteins (Vasudevan $\mathrm{N}$ et al, 2002) [5]. Gantus MA et al studied the effects of estrogen on a homogeneous stromal cell population (TS7 cells) of rat thyroid gland. Their results point to the cytokine transforming growth factor beta-1(TGF-ß1)/ transcription factor Smad-2 signaling pathway as a putative target of estrogen actions on thyroid stromal cells (Gantus MA et al, 2011) [4]. In the present study 
the serum sodium and potassium levels were significantly decreased in cases of hypothyroidism as compared to healthy controls $(\mathrm{p}<0.001)$. Our study is in conformity with the study done by Roopa $\mathrm{M}$ et al, Schwarz [20], and Jaskiran Kaur [21]. According to them, thyroid hormones regulate the activity of sodium potassium pumps in most of the tissues (Ismail Beigi $\mathrm{F}$ and Edelman IS, 1971) [8]. In hypothyroidism, because of low potassium levels, and because of deficiency of thyroid hormones, this enzyme is affected, resulting in accumulation of water inside the cells and causing oedema. This is said to be one of the mechanisms responsible for weight gain seen in hypothyroid patients. Study done by Bradley SE et al [22] observed low sodium levels in hypothyroid rats. In the rats, hypothyroidism is associated with a decrease in renal plasma flow and glomerular filtration rate and a limited urinary concentrating ability and an impairment in the renal conservation of sodium. The higher urinary sodium excretion leads to a subtle salt wasting and an exaggerated natriuretic response to extracellular fluid expansion. Our study is in conformity with the study done by Bradley et al. Our findings were contradictory to AbedelmulaM, et al where a significant increase in serum potassium levels was seen in hypothyroid patients (Abedelmula M et al, 2013) [23]. In our study total calcium levels in serum were found to be significantly lowered in hypothyroid patients when compared to controls $(\mathrm{p}<0.001)$ which is in accordance with the study done by Roopa $\mathrm{M}$ et al and Suneel B et al. Thyroxine normally regulates blood calcium levels by releasing calcium from the cells. In hypothyroidism, there is less thyroxine in the blood stream; thus less thyroxine enters the cells and less calcium is released. In the present study the serum magnesium levels were significantly increased in hypothyroid patients when compared to controls $(\mathrm{p}<0.001)$ which is in accordance with Roopa M et al, Frizel et al [17, 19] and McCaffrey et al [24] According to McCaffrey plasma magnesium tends to be elevated in hypothyroid rats presumably as a result of renal retention which has been thought to be the result of hypofiltration (McCaffrey $\mathrm{C}$ and Quamme GA,1984). In the present study serum phosphorus levels were markedly increased in cases of hypothyroidism as compared to healthy controls $(\mathrm{p}<0.001)$ which is in accordance with study done by Roopa $\mathrm{M}$ et al, Suneel B et al [19, 25] and Al- Tonsi et al[18]. Suneel B et al studied mineral status in patients of thyroid disorders (Hypo and Hyper) and found decreased calcium and increased phosphorus level in hypothyroidism mainly due to influence of PTH and calcitonin (suneel B et al 2011).

\section{Conclusion}

In this study we found that when the cases and controls were compared, there was a significant variation in the values between the studied groups. The TSH level was significantly increased in cases as compared to controls.

Total T3 and total T4 level was significantly decreased in cases as compared to controls. The present study showed maximum number of hypothyroid patients (51\%) belonged to the age group 31-40 years and there were more females than males among cases. The present study showed that there was a positive correlation between serum TSH and serum magnesium and phosphorus level and a negative correlation between serum TSH and serum sodium, potassium and calcium level. Our study demonstrated that hypothyroid patients showed low total sodium, potassium and calcium levels and increased serum magnesium and phosphorus levels. Hence monitoring of serum levels of these electrolytes and minerals during the follow up of hypothyroid cases will be of great benefit. Also, such disturbances need to be monitored at least once or twice per year and treated appropriately to avoid the ill effects resulting from the changes in their serum levels.

Funding: Nil, Conflict of interest: None initiated. Permission from IRB: Yes

\section{References}

1. Hallengren B. [Hypothyroidism--clinical findings, diagnosis, therapy. Thyroid tests should be performed on broad indications]. Lakartidningen. 1998 Sep 16;95 (38):4091-6.

2. Unnikrishnan AG, Menon UV. Thyroid disorders in India: An epidemiological perspective. Indian $\mathbf{J}$ Endocrinol Metab. 2011 Jul;15(Suppl 2):S78-81. doi: 10.4103/2230-8210.83329.

3.Vanderpump MP. The epidemiology of thyroid disease. Br Med Bull. 2011;99:39-51. doi: 10. 1093 / bmb/ldr030.

4. Gantus MA, Alves LM, Stipursky J, Souza EC, Teodoro AJ, Alves TR, Carvalho DP, Martinez AM, Gomes FC, Nasciutti LE. Estradiol modulates TGF- $\beta 1$ expression and its signaling pathway in thyroid stromal cells. Mol Cell Endocrinol. 2011 Apr 30;337(1-2):71-9. doi: 10.1016/j.mce.2011.02.001. Epub 2011 Feb 18.

5. Vasudevan N, Ogawa S, Pfaff D. Estrogen and thyroid hormone receptor interactions: physiological 
flexibility by molecular specificity. Physiol Rev. 2002 Oct;82(4):923-44.

6. Bräunlich H. Thyroid hormones influencing renal electrolyte excretion in saline loaded rats of different ages. Physiol Bohemoslov. 1984;33(4):303-8.

7. Katz AI, Lindheimer MD. Actions of hormones on the kidney. Annu Rev Physiol. 1977;39:97-133.

8. Ismail-Beigi F, Edelman IS. The Mechanism of the Calorigenic Action of Thyroid Hormone: Stimulation of $\mathrm{Na}++\mathrm{K}+$-activated adenosinetriphosphatase activity. J Gen Physiol. 1971 Jun 1; 57(6): 710-722.

9. Capasso G, De Tommaso G, Pica A, Anastasio P, Capasso J, Kinne R, De Santo NG. Effects of thyroid hormones on heart and kidney functions. Miner Electrolyte Metab. 1999 Jan-Apr;25(1-2):56-64.

10. Adrogué HJ, Madias NE. N Engl J Med. 2000 May 25;342(21):1581-9.

11. Gross P, Benzing T, Hensen J, Mönig H. [Practical approach to hyponatremia]. Dtsch Med Wochenschr. 2011 Aug; 136 (34-35):1728-32. doi: 10.1055/s-00311286066. Epub 2011 Aug 29.

12.Schmitt R, Klussmann E, Kahl T, Ellison DH, Bachmann S. Renal expression of sodium transporters and aquaporin-2 in hypothyroid rats. Am J Physiol Renal Physiol. 2003 May;284(5):F1097-104. Epub 2003 Feb 4.

13. Kinoshita I, Usa T, Satoh A, Tsujihata M. [A case of hypothyroidism associated with hypokalemic periodic paralysis]. Rinsho Shinkeigaku. 1990 Jan; 30(1):100-2.

14. Saruta T, Kitajima W, Hayashi M, Kato E, Matsuki $\mathrm{S}$. Renin and aldosterone in hypothyroidism: relation to excretion of sodium and potassium. Clin Endocrinol (Oxf). 1980 May;12(5):483-9.

15. Shivaleela MB, PoornimaRT ,Jayaprakash Murthy DS. Serum Calcium and Phosphorous levels in thyroid dysfunction. Indian Journal of Fundamental and Applied Life Sciences. 2012;2(2):179-183.
16. Alcalde AI, Sarasa M, Raldúa D, Aramayona J, Morales R, Biber J, Murer H, Levi M, Sorribas V. Role of thyroid hormone in regulation of renal phosphate transport in young and aged rats. Endocrinology. 1999 Apr;140(4):1544-51.

17. Frizel D, Malleson A, Marks V. Plasma levels of ionised calcium and magnesium in thyroid disease. Lancet. 1967 Jun 24;1(7504):1360-1.

18. Al-Tonsi AA, Abdel-Gayoum AA, Saad M. The secondary dyslipidemia and deranged serum phosphate concentration in thyroid disorders. ExpMolPathol. 2004 Apr; 76 (2):182-7. doi: 10.1016/j. yexmp. 2003. 10.006

19. Roopa M, Gladys S. Changes in electrolyte and lipid profile in hypothyroidism. International Journal of Life Science and Pharma Research. 2012:2(3):185-194.

20. Schwarz C, Leichtle AB, Arampatzis S, Fiedler GM, Zimmermann H, Exadaktylos AK, Lindner G. Thyroid function and serum electrolytes: does an association really exist? Swiss Med Wkly. 2012 Sep 17;142:w13669. doi: 10.4414/smw.2012.13669.

21. Kaur J, Ahmad N, Gupta A. Changes in electrolyte profile of patients having hypothyroidism. Journal of Medical Science and Clinical Research.2014.2(4):63337.

22. Bradley SE, Stéphan F, Coelho JB, Réville P. The thyroid and the kidney. Kidney Int.1974 Nov; 6(5):34665 .

23. Abedelmula M, Abdealla L, Fadwa AS. Serum electrolytes and Bone mineral status in Sudanese patients with thyroid dysfunction.Neelain Medical journal. 2013.3(12); 52-60.

24. McCaffrey C, Quamme GA. Effects of thyroid status on renal calcium and magnesium handling. Can $\mathbf{J}$ Comp Med. 1984 Jan;48(1):51-7.

25. Suneel B, Nagendra D R, Aparna R R, Balakrishna D, Naidu J N. Mineral status in thyroid disorders (hypo \& hyper). International Journal of Applied Biology and PharmaceuticalTechnology.2011Oct-Dec;2(4):423-429.

\section{How to cite this article?}

Padhiary M, Mishra T, Mohanty R.R., Mishra S, Mishra S.K. Study of serum electrolytes and minerals in hypothyroidism. Int J Med Res Rev 2016;4 (7):1189-1193.doi:10.17511/ijmrr.2016.i07.19. 